\title{
MULTIMEDIA INTERAKTIF 3 DIMENSI PENGENALAN STASIUN LUAR ANGKASA INTERNATIONAL SPACE STATION (ISS)
}

\author{
${ }^{1}$ Lalu Jayeng rusiandi Putra, ${ }^{2}$ Danang Tejo Kumoro \\ ${ }^{1}$ Mahasiswa, ${ }^{2}$ Dosen Program Studi Teknik Informatika, STMIK Bumigora Mataram \\ JL. Ismail Marzuki Mataram, NTB \\ 1ayenkputra@gmail.com. ${ }^{2}$ danangmoro@gmail.com
}

\begin{abstract}
International Space Station (ISS) is one of the greatest achievements in modern science especially in astronomy and engineering. The main function of the ISS is as an aerospace laboratory to conduct research and experiments related to the space environment which can not be done on earth. For the students in high schools, especially in MA Nurul Iman, there are still many who do not know the existence and function of the details of International Space Station (ISS). Therefore, it needs an interactive recognition media where users can see and know the function of the ISS more clearly and more interactive than the video or print media. The result of this thesis is an interactive multimedia introduction of International Space Station (ISS) International Space Station (ISS) the ISS and the ISS station parts functions. The results that can be drawn from making this application are effective for use as information medium introducing International Space Station (ISS).
\end{abstract}

Kata Kunci: International Space Station, Astronomi, Engineering, Multimedia interaktif.

\section{PENDAHULUAN}

International Space Station (ISS) adalah stasiun luar angkasa internasional yang merupakan proyek gabungan bebarapa negara seperti Amerika Serikat, Rusia, Jepang, dan beberapa negara Uni Eropa. ISS adalah salah satu proyek astronomi terbesar dan merupakan objek termahal yang pernah dibuat senilai milyaran dolar amerika serikat. ISS menjadi salah satu pencapaian terbesar dalam ilmu pengetahuan modern terutama di bidang astronomi dan engineering. Fungsi utama dari ISS ini adalah sebagai laboratorium luar angkasa untuk melakukan riset dan eksperimeneksperimen yang berkaitan dengan lingkungan luar angkasa yang dimana tidak bisa dilakukan di bumi. Hasil riset dan eksperimen-eksperimen tersebut digunakan dan diterapkan dalam kehidupan sehari-hari [8].

Hasil riset yang dilakukan di Stasiun luar angkasa dapat dijadikan acuan sebagai pengetahuan ataupun data yang relavan tentang keadaan luar angkasa dan alam semesta ini. Pengetahuan tentang luar angkasa, planet, galaxy, sampai bentuk permukaan bumi dan planet lainnya merupakan hasil riset yang dilakukan di Stasiun Luar Angkasa International. Semua pengetahuan tentang informasi tersebut kemudian di terapkan sebagai salah satu sumber informasi yang diambil dalam materi pembelajaran dalam dunia Pendidikan yang ada.

Informasi yang berkaitan dengan alam semesta secara fisik dan fungsinya dapat kita peroleh dalam materi pembelajaran Geografi dan Astronomi. Dalam materi geografi secara spesifik dibahas tentang tata surya dan alam semesta mulai dari teori terbentuknya hingga materi penyusunnya. Geografi menjadi satu disiplin ilmu yang mempermudah manusia untuk mengenal alam semesta ini.

Berdasarkan manfaat besar yang dapat di nikmati melalui hasil riset yang dilakukan pada stasiun luar angkasa ini 
membuat penulis mencoba untuk memperkenalkan lebih jauh tentang stasiun luar angkasa internasional (ISS) melalui media interaktif 3 dimensi dengan harapan dapat menjadi landasan pengetahuan yang membuat kita lebih mengenal stasiun luar angkasa secara bentuk dan fungsinya. Hal ini dilakukan dengan harapan menumbuhkan pengetahuan siswa tentang materi yang diterimanya selama ini merupakan sebuah hasil dari riset yang panjang dan memanfaatkan teknologi yang canggih.

Bagi kalangan pelajar di SMA khususnya Di Nusa Tenggara Barat masih banyak yang belum mengetahui keberadaan dan fungsi lebih detail dari International Space Station (ISS) ini dimana ISS menjadi proyek besar umat manusia dimasa sekarang dan dimasa mendatang. Oleh karena itu akses informasi mengenai fungsi dan tujuan ISS yang mudah dan efisien menjadi sangat penting. Hal ini bisa dilakukan dengan cara membuat sebuah media informasi berbasis multimedia.

Aplikasi pengenalan stasiun luar angkasa internasional ISS ini adalah multimedia interaktif yang berfungsi sebagai media pengenalan stasiun. Informasi mengenai stasiun yaitu fungsi dan tujuan lebih detail dari masing-masing bagian stasiun dapat diakses oleh pengguna secara interaktif.

Multimedia interaktif pengenalan International Space Station (ISS) ini merupakan sarana pengenalan stasiun luar angkasa dimana bertujuan memudahakan pengguna mengakses informasi terkait tujuan dan fungsi lebih detail dari stasiun luar angkasa ISS yaitu modul-modul (modules), truss dan airlock dari stasiun melalui teknologi 3 Dimensi yang bersifat interaktif.

Tujuan dari penulisan ini yaitu :

Tujuan pembuatan media interaktif ini adalah menyediakan media pengenalan bagi kalangan pelajar di SMA khususnya Di Nusa Tenggara Barat untuk menambah pengetahuan tentang stasiun luar angkasa internasional ISS melalui media 3 Dimensi

Setasiun luar angkasa ini awalnya direncanakan sebagai sebuah "Stasiun Angkasa Freedom" NASA dan dipromosikan oleh Presiden Reagan, dan kemudian diketahui karena terlalu mahal maka proyek ini di berhentikan. Setelah berakhirnya Perang Dingin, proyek ini diadakan kembali sebagai proyek gabungan NASA dan Rosaviakosmos Russia. Untuk membantu membangun proyek ini, pada 1 Desember 1987, NASA mengumumkan empat nama perusahaan AS yang akan diberikan kontrak untuk menolong membuat bagian dari Stasiun Angkasa, berikut nama Perusahaanya : Boeing Aerospace, AstroSpace Division General Electric, McDonnell Douglas, dan Rocketdyne Division Rockwell.

Seksi pertama ditaruh di orbit pada 1998. Dua bagian lainnya ditambahkan sebelum awak pertama dikirim. Awak pertama tiba pada 2 November, 2000 dan terdiri dari astronot AS William Shepherd dan dua kosmonot Russia, Yuri Gidzenko dan Sergei Krikalev. Mereka memutuskan untuk memanggil stasiun angkasa tersebut "Alpha" tetapi penggunaan nama tersebut dibatasi hanya misi mereka.

Karena jadwalnya sering terlambat. Sebenarnya setasiun ini di perkirakan bisa menempatkan tujuh awak akan tetapi sampai tahun 2003 belum bisa, oleh Karena itu cara NASA menanggulanginya adalah dengan membatasi jumlah ilmiah akan tetapi membuat partner eropapada proyek ini marah. Akhirnya pada tahun 2004 NASA menyelesaikan setasiun yang di mana akan dapat di tempati oleh 4 awak dan akan meluncurkan seksi tambahan seperti modul eksperimen Jepang. NASA akan melanjutkan menangani konstruksi dan Rusia akan terus meluncurkan dan mengganti awak stasiun [10]. 
Menurut [3] "misi dari program stasiun luar angkasa internasional ISS adalah untuk memajukan ilmu pengetahuan dan riset teknologi, mengembangkan wawasan pengetahuan umat manusia, menginspirasi dan mengedukasi generasi penerus, membantu perkembangan pengembangan komersial dari program luar angkasa dan mendemonstarsikan kemampuan untuk mengadakan misi explorasi luar angkasa.

ISS adalah satu-satunya platform dengan durasi lama (long-duration platform) dalam program luar angkasa dengan teknologi dan arsitektur yang bisa diguanakan untuk mendemonstarasikan teknologi dan konsep terdepan dan maju dalam program luar angkasa. ISS bekerja dan berkolaborasi dengan komunitas program eksplorasi luar angkasa internasional dimana ISS mampu mendukung semua area kebutuhan penelitan terkait riset program eksplorasi luar angkasa. Program International Space Station bertujuan untuk mendemonstrasikan hal-hal tersebut diatas dan beberapa teknologi lainnya pada stasiun luar angkasa dimana mereka bisa mengevaluasi tanpa resiko yang signifikan terhadap crew atau kendaraan agar mampu mengakselerasikan pengembangan dan mengurangi resiko misi penjelajahan kedepan selanjutnya [3].

International Space Station (ISS) merupakan platform ilmu pengetahuan yang unik dimana dengannya para peneliti dari berbagai belahan dunia mampu mengembangakan dan menyalurkan talenta mereka pada riset dan penelitan ilmiah yang bermanfaat bagi umat manusia. Manfaatmanfaat ini bisa dikategorikan menjadi 3 kategori yaitu:

a. Manfaat bagi umat manusia

b. Penemuan ilmiah

c. Memungkinkan eksplorasi luar angkasa masa depan

Dari kategori-kategori manfaat tersebut diatas, hal tersebut bisa dibagi menjadi beberapa tema manfaat sebagai berikut: a. Dunia kesehatan

b Observasi bumi dan respon bencana

c Teknologi inovatif

d Pendidikan global

e Pengembangan ekonomi luar angkasa

International Space Station (ISS) adalah sebuah laboratorium unik untuk melakukan investigasi yang berpengaruh bagi kesehatan manusia baik itu di bumi maupun di luar angkasa. Selama mengorbit, stasiun menyediakan sebuah kemampuan untuk melakukan riset yang memberikan kita pemahaman lebih baik tentang berbagai aspek dari kesehatan manusia seperti penuaan (aging), trauma, penyakit dan pengaruh-pengaruh lingkungan. Terdorong oleh kebutuhan untuk mendukung dan menjaga kesehatan astronot, beberapa hasil penelitan biologis dan investigasi psikologis manusia menghasilkan sebuah manfaat yang dapat dirasakan umat manusia yang berada di bumi [7].

International Space Station (ISS) adalah sebuah observasi global dan stasiun diagnosis (diagnosis station). ISS mempromosikan observasi bumi dari luar angkasa yang bertujuan untuk memahami dan memecahkan masalah dan isu-isu lingkungan dari planet kita bumi. Berbagai alat observasi bisa dihubungkan langsung dengan fasilitas yang ada di stasiun terutama bagian eksterior stasiun. Keberadan dan ketersedian crew juga menyediakan kapabilitas unik untuk observasi real-time dan "on the fly" planet bumi [7].

Di luar angkasa, proses fisik dapat dipahamai lebih baik dengan kontrol terhadap pengaruh-pengaruh eksternal seperti gravitasi. Inovasi-inovasi teknis yang telah didesain untuk system luar angkasa diuji coba di International Space Station (ISS) sebelum digunakan pada pesawat luar angkasa lainnya. Selama prosess investigasi tentang bagaimana teknologi- teknologi baru beroperasi di luar angkasa, penemuanpenumuan tak terduga merupakan bukan hal yang mustahil. Sistem fisik yang simpel 
(simplified physical system) bisa juga digunakan langsung untuk mengembangkan model-model proses fisik yang mengarahkan kita kepada teknik-teknik industry baru [7].

International Space Station (ISS) memiliki kapabilitas unik untuk menangkap imajinasi baik itu para pelajar dan guru seluruh dunia.Keberadaan manusia di dalam stasiun menyediakan sebuah fondasi untuk berbagai macam kegiatan edukasi yang ditunjukkan untuk menarik ketertarikan dan memotivasi anak-anak untuk mempelajari ilmu pengetahuan, teknologi, engineering dan matematika (STEM). Proyek seperti Amateur Radio in International Space Station (ARISS), Earth Knowledge Acquired by Middle School Students (EarthKAM), Synchronized Position Hold, Engage, Reorient Experimental Satellites (SPHERES), Zero Robotics Competition merupakan salah satu contoh kecil yang menyediakan akses informasi kepada para pelajar dan guru secara [7].

Selain sebagai sebuah platform penelitian dan pengembangan teknologi, International Space Station (ISS) merupakan sebuah platform yang menyediakan kesempatan-kesempatan ideal untuk menguji coba hal-hal baru dalam hubungan-hubungan bisnis. Dengan hal ini maka terdapat kesempatan untuk beralih dari paradigma bisnis yang dibiayai pemerintah (government-funded), dan kebutuhan barang yang dibiayai kontraktor (contractorprovider goods) menjadi sebuah paradigma yang disediakan secara komersial (commercially-provided) dengan sebuah pendekatan dimana pemerintah sebagai costumer [8].

International Space Station (ISS) adalah merupakan sebuah eksperimen dalam desain, pengembangan dan perakitan fasilitas orbit luar angkasa. Desain modular dari ISS didikte dengan bagian-bagian yang di luncurkan oleh kendaraan muatan. Modul-modul dari ISS berfungsi sebagai habitat untuk para crew dan menyediakan pelabuhan dan dermaga untuk suplai pesawat [9].

International Space Station (ISS) dibangun bagian demi bagian secara bertahap di orbit. ISS terdiri dari modulmodul dan node-node yang terkoneksi dimana terdapat tempat tinggal dan laboratorium-laboratorium, termasuk juga bagian eksternal-eksternal lainnya yang menyediakan pendukung bagi struktur stasiun dan solar panel yang menyediakan daya dan tenaga bai stasiun [8].

Internasional Space Station (ISS) secara garis besar terdiri berbagai bagian utama yaitu module, truss dan airlock. Module merupakan bagan atau unit dari kendaraan angkasa (spacecraft). Truss adalah merupakan balok/tiang yang berfungsi sebagai tulang punggung dari stasiun luar angkasa dimana sebagian bagian stasiun terkoneksi. Dan yang terakhir adalah airlock yaitu merupakan sebuah ruang dengan dua pintu masuk yang mengizinkan astronot untuk keluar dari stasiun tanpa membiarkan oksigen keluar dari stasiun luar angkasa [10].

Proses perakitan dari International Space Station (ISS) sudah dimulai sejak tahun 1990-an. Zarya Adalah modul ISS pertama yang diluncurkan oleh roket Proton pada tanggal 20 November 1998. Dimana pengembangan terus dilakukan sejak saat peluncuran pertama tersebut [2].

Perakitan International Space Station (ISS) komplit pada tahun 2010 merupakan dan menjadi objek buatan manusia terbesar yang pernah mengorbit bumi. ISS memiliki volume sebesar $860 \mathrm{~m} 3$ dan massa sebesar $399.380 \mathrm{~kg}$ termasuk kendaran Soyuz. Panel surya bisa menutupi area seluas $2.247 \mathrm{~m} 2$ dan mampu menghasilkan tenaga listrik sebesar 735.840 $\mathrm{kW}$ pertahun [2].

Dalam merakit ISS dibutuhkan 36 penerbangan pesawat ulang alik dan 5 kapal peluncur Russia dimana untuk saat ini 
logistik dan suplai ulang disediakan melalui kendaraan-kendaran luar angkasa seperti pesawat ulang alik, Soyuz dan lain sebagainya [2].

Sebagaimana telah disebutkan sebelumnya bahwa International Space Stasiun (ISS) terdiri dari berbagai macam bagian-bagian utama seperti module, truss dan airlock.

Berikut modul-modul dari stasiun luar angkasa internasional ISS :

a. Functional Cargo Block (FGB)

b. Nodes

c. U.S. Laboratory (LAB)

d. Permanent Multipurpose Module (PMM)

e. Russian Docking Compartment (DC) Pirs

f. Mini-Research Module 2 (MRM2) Poisk (Explore)

g. Sevice Module (SM) Zvezda (Star)

h. Pressurized Mating Adapters (PMAs)

i. Copula

j. ESA Columbus Module

k. Japanese Experiment Module Kibo (Hope)

Truss adalah merupakan balok/tiang yang berfungsi sebagai tulang punggung dari stasiun luar angkasa dimana sebagian bagian stasiun terkoneksi. Berikut daftar Truss yang sudah terpasang di stasiun luar angkasa ISS sampai tahun 2011 :

a. Zenith 1 (Z1) Truss,

b. PMA 3 ,Port 6 (P6) Truss,

c. Starboard Zero (S0) Truss and Mobile Transporter,

d. S1 Truss and Crew Equipment Translation Aid (CETA) Cart,

e. P1 Truss and CETA Cart,

f. P3/P4 Truss, P5 Truss,

g. Retracing P6 Arrays,

h. S3/S4 Truss,

i. S5 Truss and ESP-3,

j. S6 Truss

Airlock merupakan modul atau bagan stasiun yang berfungsi sebagai sebuah ruang dengan dua pintu masuk yang mengizinkan astronot untuk keluar dari stasiun tanpa membiarkan oksigen keluar dari stasiun luar angkasa [8].

a. Joint Airlock Quest

b. Russian Docking Compartment (DC) Pirs

c. Solar Array

\section{METODELOGI}

\section{Metode Pengumpulan Data}

\section{Wawancara}

Mengadakan wawancara atau tanya jawab dengan pihak Madrasah Aliya Nurul Iman untuk memperoleh informasi yang berkaitan --dengan materi pembelajaran geografi tentang luar angkasa dan tata surya. Hal ini dilakukan untuk mendapat gambaran tentang tingkat kesulitan materi serta konsultasi tentang kebutuhan media bantu dalam proses pembelajaran.

\section{Studi Literatur}

Studi literatur dilakukan dengan tujuan mengumpulkan dan mempelajari beberapa literatur yang berkaitan dengan skripsi ini untuk mendapatkan pemahaman materi yang baik yang berkaitan dengan permasalahan ini sehingga dapat dijadikan sebagai referensi. Studi literatur dilakukan dengan cara mencari beberapa sumber ilmiah seperti buku, jurnal dan beberapa website yang berkaitan dengan permasalahan yang dibahas dalam skripsi ini. Informasi yang diperoleh dari studi literatur yang dilakukan yaitu beberapa teori tentang International Space Station (ISS), gambar serta model dari komponen ISS yang digunakan dalam proses desain objek 3 dimensi, serta cara atau referensi desain dan pembuatan aplikasi dengan menggunakan Unity $3 D$.

\section{Metod Pengembnagn Aplikasi}

Metodologi yang digunakan dalam membuat media pengenalan ini 
adalah dari Luther - Sutopo. Beliau berpendapat bahwa metode Pengembangan perangkat lunak multimedia terdiri dari 6 tahapan yaitu :

\section{a. Concept}

Tahap concept (konsep) adalah tahap untuk menentukan tujuan dan siapa pengguna program (identifikasi audience). Selain itu menentukan macam aplikasi (presentasi, interaktif, dll) dan tujuan aplikasi (hiburan, pelatihan, pembelajaran, dll).

b. Design

Design (perancangan) adalah tahap membuat spesifikasi mengenai arsitektur program, gaya, tampilan dan kebutuhan material / bahan untuk program.

\section{c. Material Collecting \\ Material Collecting adalah} tahap dimana pengumpulan bahan yang sesuai dengan kebutuhan dilakukan. Tahap ini dapat dikerjakan paralel dengan tahap assembly. Pada beberap kasus, tahap Material Collecting dan tahap Assembly akan dikerjakan secara linear tidak paralel.

d. Assembly

Tahap assembly (pembuatan) adalah tahap dimana semua objek atau bahan multimedia dibuat. Pembuatan aplikasi didasarkan pada tahap design.

e. Testing

Dilakukan setelah selesai tahap pembuatan (assembly) dengan menjalankan aplikasi/program dan dilihat apakah ada kesalahan atau tidak. Tahap ini disebut juga sebagai tahap pengujian alpha (alpha test) dimana pengujian dilakukan oleh pembuat atau lingkungan pembuatnya sendiri.

\section{f. Distribution}

Pada tahap ini, aplikasi akan disimpan dalam suatu media penyimpanan. Jika media penyimpanan tidak cukup untuk menampung aplikasinya, kompresi terhadap aplikasi tersebut akan dilakukan. Tahap ini juga dapat disebut tahap evaluasi untuk pengembangan produk yang sudah jadi supaya menjadi lebih baik. Hasil evaluasi ini dapat digunakan sebagai masukan untuk tahap concept pada produkjselanjutnya.

\section{HASIL DAN PEMBAHASAN}

\section{Hasil}

Hasil dari aplikasi ini berupa file dengan format exe yang dapat diinstal pada Personal Computer (PC) atau laptop. Kapasitas file dari aplikasi ini setelah di build kedalam format exe sebesar 17,3 MB. Berdasarkan format default dari aplikasi unity dengan lisensi gratis akan ada pilihan untuk ukuran layar aplikasi pada saat di jalankan sebelum masuk pada aplikasi itu sendiri. Dari hasil yang dibuat, aplikasi ini memiliki beberapa halaman diantaranya adalah, Halaman Menu Utama, Apa Itu ISS, Pelajari, dan Halaman Penjelasan Bagian ISS.

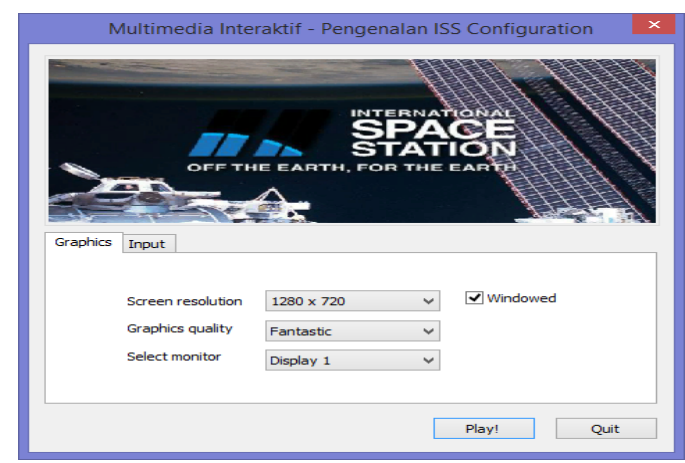

Gambar 3.1 : Halaman Konfigurasi Graphics Aplikasi

\section{Hasil Halaman Menu Utama}

Pada menu utama terdapat tampilan dengan mengkombinasikan background objek 3 dimensi bumi dan objek 3 dimensi ISS. Pada menu ini juga terdapat 3 button yang dapat diakses oleh pengguna untuk menuju halaman yang diinginkan atau bahkan keluar dari aplikasi. Penempatan button diletakkan pada bagian kiri bawah dengan harapan 
dapat memberikan tampilan yang lebih luas pada objek 3D yang ada.

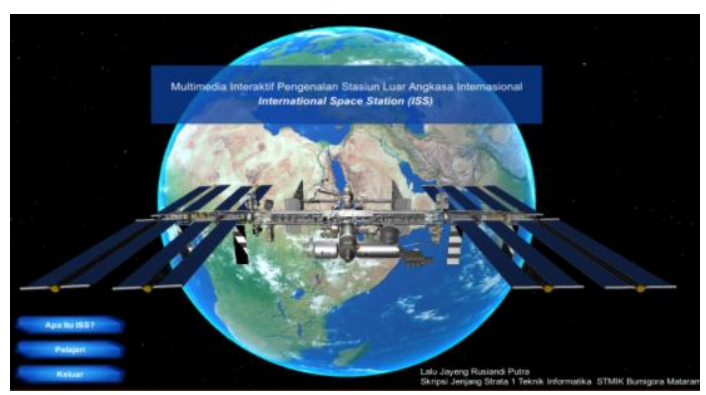

Gambar 3.2 : Halaman Menu utama

\section{Hasil Halaman Apa Itu ISS?}

Pada halaman ini pengguna akan mendapatkan informasi tentang apa itu ISS. Informasi yang diberikan berkaitan dengan sejarah dan segala hal tentang ISS serta menampilkan bentuk 3D dari International Space Station (ISS) yang dapat di zoom in atau zoom out untuk dapat melihat detail yang ada pada ISS tersebut. Pada halaman ini juga terdapat navigasi atau button kembali yang dapat mengarahkan pengguna menuju halaman Menu Utama sehingga pengguna dapat mengakses halaman yang lainnya.

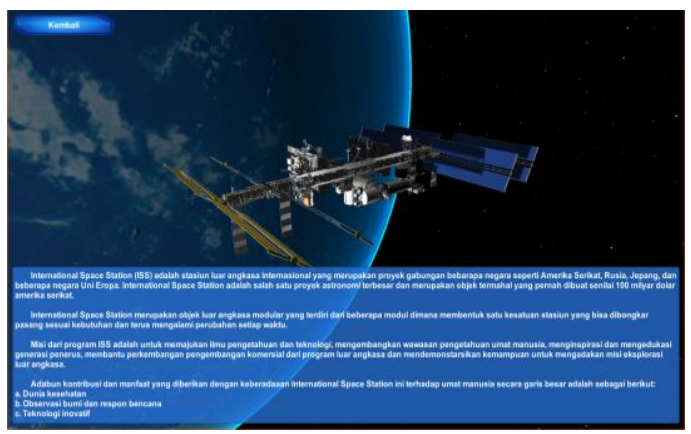

Gambar 3.3 :Halaman Menu penjelasan ISS

\section{Hasil Halaman Pelajari}

Pada halaman ini terlihat lebih padat dengan halaman halaman yang lainnya. Halaman ini terdiri dari bentuk 3D dari bumi, Objek ISS dan beberapa button dengan nama bagian-bagian dari objek yang menyusun ISS untuk dapat diakses sehingga pengguna dapat di alihkan kepada Halaman Penjelasan Bagian-bagian ISS. Pada halaman ini juga terdapat button Menu Utama yang dapat diakses jika pengguna ingin kembali kemenu utama untuk mengakses bagian aplikasi yang lainnya.

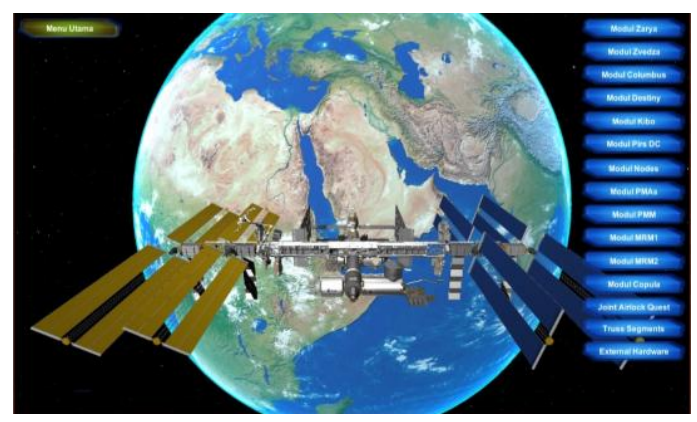

Gambar 3.4 : Halaman Menu pelajari

\section{Hasil Halaman Penjelasan Bagian ISS}

Halaman ini merupakan halaman yang dapat diakses melauli beberapa button tentang nama dari objek penyusun ISS yang terdapat pada halaman Pelajari. Pada halaman ini pengguna akan diberikan informasi terkait dengan objek penyusun dari ISS secara lebih detail dengan menampilkan satu persatu bagian yang dipilih. Objek akan ditampilkan dengan tampilan 3D dan akan ada penjelesan mengenai objek tersebut dalam susunan beberapa teks.

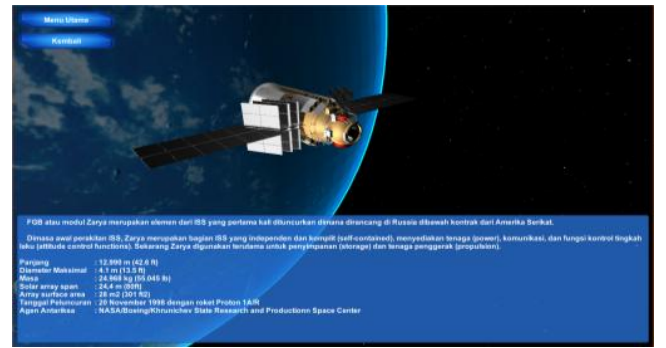

Gambar 3.5 : Menu penjelasan modul FGB Zarya 
Selain Menu Penjelasan Modul FGB Zarya masih ada lagi Penjelsanpenjelasan, diantaranya :

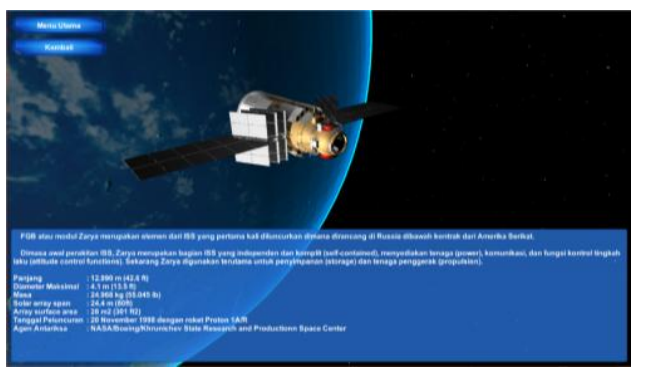

Gambar 3.6 : Menu penjelasan modul SM Zvedza

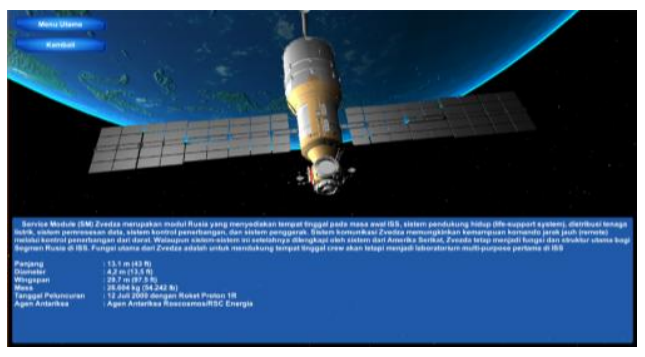

Gambar 3.7 : Menu penjelasan modul Columbus.

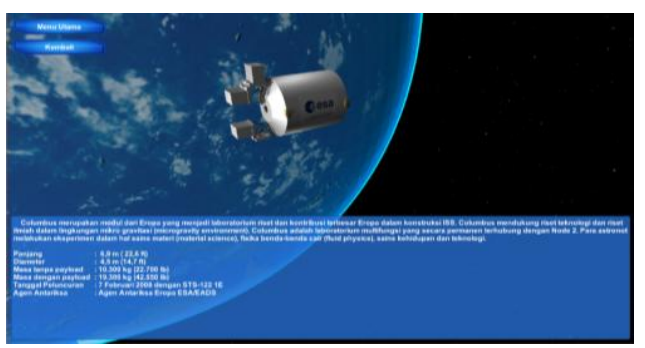

Gambar 3.8 : . Menu penjelasan modul Destiny.

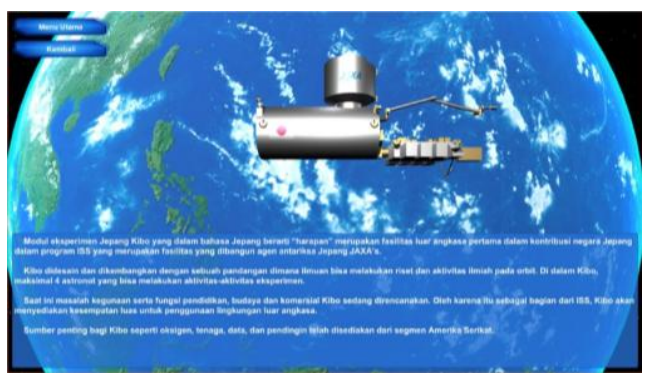

Gambar 3.9 : Menu penjelasan modul Kibo.

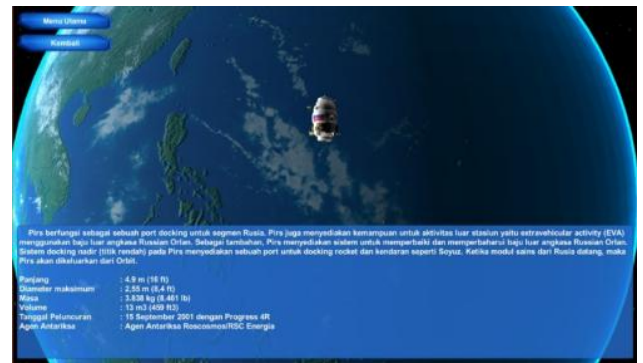

Gambar 3.10 : Menu penjelasan modul Pirs DC.

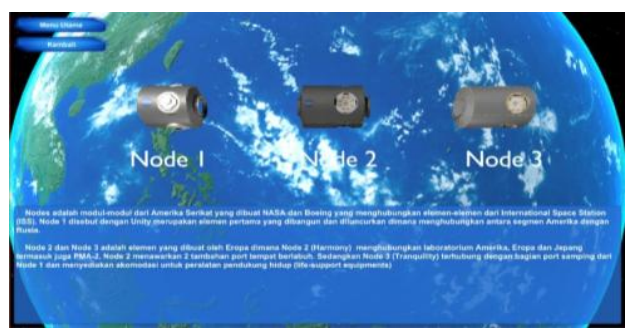

Gambar 3.11 : Menu penjelasan modul Nodes.

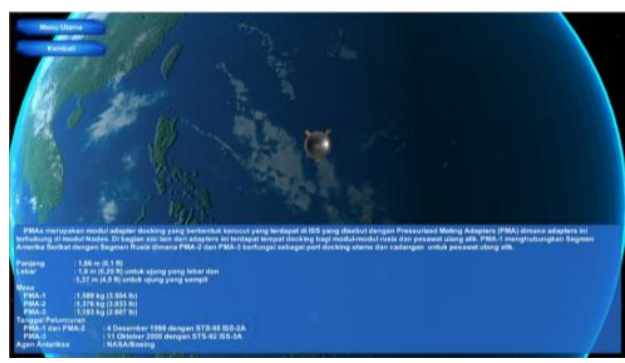

Gambar 3.12 : Menu penjelasan modul PMAs.

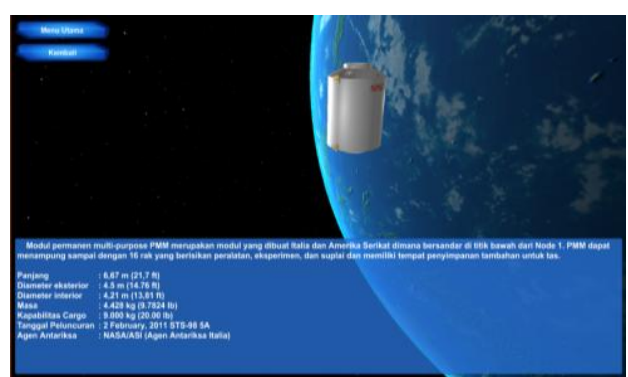

Gambar 3.13 : Menu penjelasan modul MRM1 Rassvet.. 


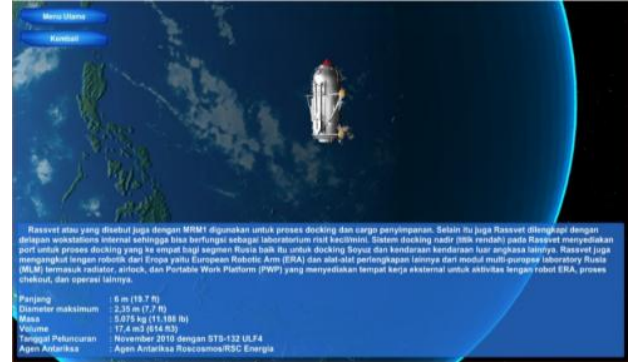

Gambar 3.14 : Menu penjelasan modul MRM1 Rassvet..

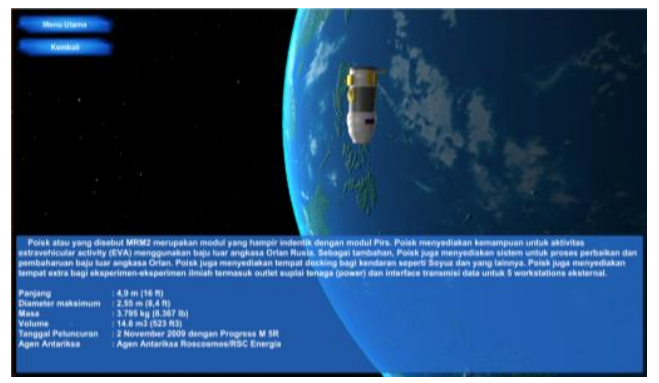

Gambar 3.15 : Menu penjelasan modul MRM2 Poisk.

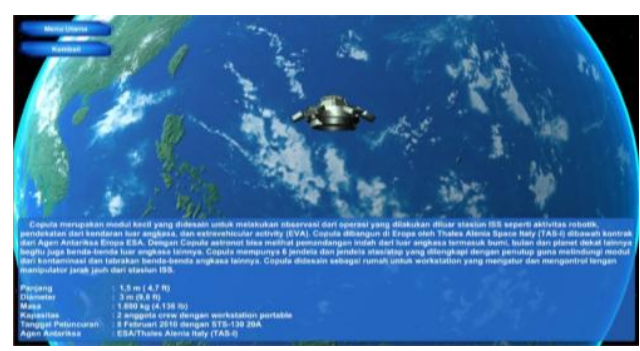

Gambar 3.16 : Menu penjelasan modul Copula.

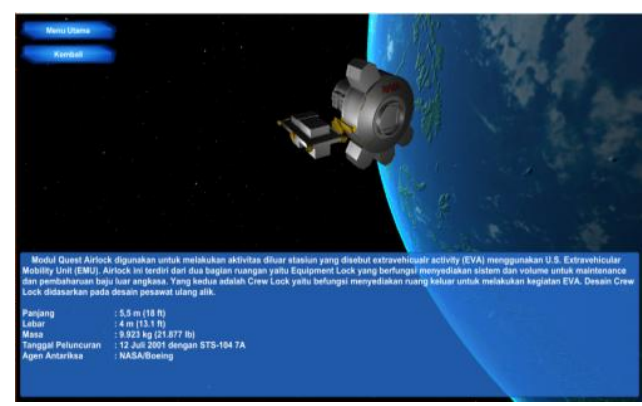

Gambar 3.17 : Menu penjelasan modul Joint Quest Airlock.

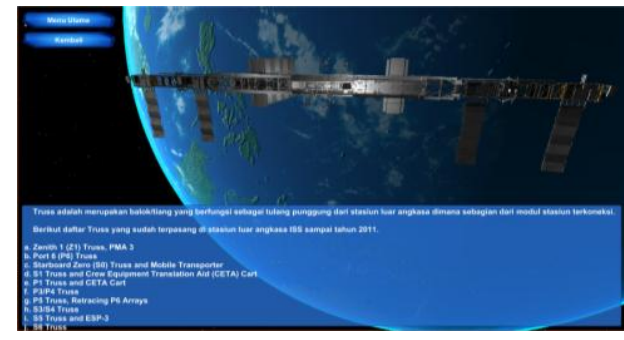

Gambar 3. 18: Menu penjelasan Truss Segments.

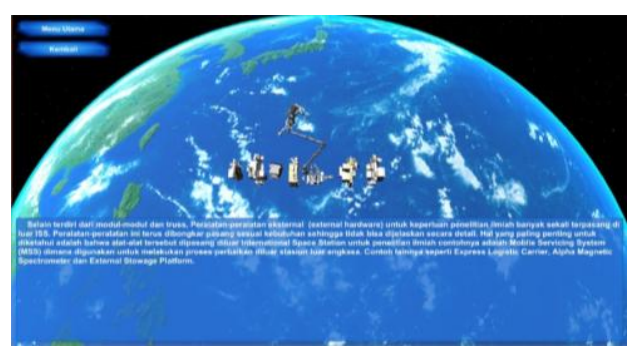

Gambar 3. 19: Menu penjelasan modul External Hardware.

\section{SIMPULAN DAN SARAN}

\section{Kesimpulan}

Berdasarkan hasil analisa dan pembahasan serta hasil uji coba program pada skripsi yang ini maka dapat diambil kesimpulan bahwa aplikasi ini efektif untuk digunakan sebagai media informasi memperkenalkan International Space Station (ISS). Hal ini dapat dilihat dari hasil pengujian oleh pengguna dengan hasil persentase tingkat setuju dan sangat setuju dari pengguna lebih tinggi pada beberapa indikator pertanyaan yang dijadikan acuan untuk menilai efektifitas dari aplikasi ini.

\section{Saran}

Melihat permasalahan yang ada dan sistem kerja dari aplikasi ini maka untuk kesempuraan dari pemecahan masalah ini ada beberapa saran yang dapat digunakan jika dilakukan pengembangan pada aplikasi ini, yaitu:

1. Aplikasi ini masih memiliki penjelasan yang tidak terlalu lengkap dikarenakan kurangnya 
referensi yang tersedia sehingga diharapkan kedepannya aplikasi ini dapat lebih dilengkapi.

2. Objek 3dimensi yang ditampilakn hanya dapat dilihat dari bagian luar karena keterbatasan kemampuan penulis untuk mendesain objek 3D yang ada sehingga kedepan diharapkan dapat ditingkatkan dengan tampilan bentuk ISS dari sudut pandang bagian dalamnya.

3. Aplikasi ini masih bersifat offline dan di harapkan nantinya dapat diintegrasikan langsung dalam waktu akses yang realtime dengan cara online di internet.

\section{UCAPAN TERIMAKASIH}

Terima kasih kepada STMIK Bumigora Mataram dan Madrsah Aliyan Nurul Iman Dasan Makam, Setanggor, Kec. Sukamulia Lombok Timur.

\section{REFERENSI}

[1] Binanto, Iwan. (2010). Multimedia Digital Dasar Teori + Pengembangannya. Andi:Yogyakarta.

[2] Brian, Dunbar.

,https://www.nasa.gov/audience/forstudents /k-4/stories/nasa-knows/what-is-the-iss-

k4.html, diakses tanggal 7 Pebruari, 2017

[3] David M. Hornyak (2013). ISS Tech Demo, Researcher Guides, Website Nasa.

[4] Goldstone . (2009). Unity Game Development Essentials. Packt Publishing.

[5] Hendratman, Hendi. (2015). The Magic of Blender 3D Modelling. Informatika.

[6] NASA, Pengarang NASA (tidak ada disebutkan nama spesifik) (2010), Reference
Guide to The International Space Station, Washington DC.

[7] Robinson, Julie et all. (2015). International Space Station Benefits for Humanity, Second Edition.

[8] Sharp, Tim. (2016) ,http://www.space.com/16748-internationalspace-station.html, diakses tanggal 7 Pebruari 2017.

[9] Teitel, Amy Shira (2015), http://www.popsci.com/brief-history-spacestations-before-iss, diakses tanggal 17 Pebruari 2017. 
